\title{
Contrasting Images of the Book of Revelation in Late Medieval and Early Modern Art: A Case Study in Visual Exegesis, by Natasha F.H. O'Hear
}

Oxford Theological Monographs | Oxford: Oxford University Press, 20 I I $\mid$ xvii + 287 pages | ISBN: 978-0-19-9590 I0-0 (hardback) $£ 83.00$

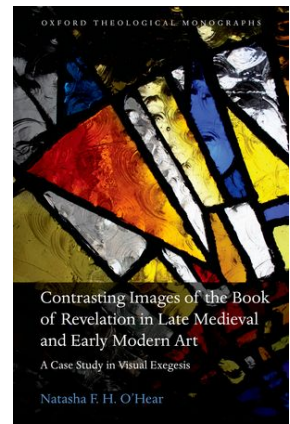

This volume, based on the author's doctoral work undertaken at Oxford, explores the visual reception of the Book of Revelation in the late medieval and early modern periods. Noting that the traditional focus on written exegesis concerning Revelation presents a "danger of distorting the interpretation of this most visual of biblical books" (I), this study explores seven diverse visual depictions, touching on historical, artistic, and exegetical questions along the way. Beyond this, O'Hear also seeks "to understand the different ways in which images themselves exhibit hermeneutical strategies akin to those found in textual exegesis" (3).

The first chapter looks at the Lambeth Apocalypse, a thirteenth-century manuscript that comes from the Anglo-Norman illustrated manuscript tradition. Produced for an aristocratic female patron, this manuscript contains both text and image, with the text taking a more prominent role in this instance. Visual themes run throughout the illustrations in the Lambeth, in- 
cluding depictions that would appear to contextualise the work historically, notably a focus on the elect and the reprobate as well as anti-Jewish iconography. Numerous interesting questions arise from this examination, in particular the relation of imaging the text as opposed to exegetical traditions (both seem to be present), as well as the function that visual depictions might have had for those unable to read the Latin text.

The next chapter explores "The Angers Apocalypse Tapestry: A FourteenthCentury Walking Tour of the Book of Revelation.” This work, begun in I 373 for Louis I of Anjou, was very much a status symbol demonstrating wealth and power; indeed, the fact that it incorporates personal iconography into the biblical imagery (e.g., angels bearing the arms of Anjou) is noticeable given that many read Revelation as a critique of imperial power. The tapestry, which originally measured I $30 \mathrm{~m}$ long and $4.5 \mathrm{~m}$ high, is "the largest surviving narrative representation of the Book of Revelation" (43). In light of this, O'Hear focuses on the format, size and layout of the Angers, paying particular attention to its visual impact. O'Hear suggests that the Angers creates a world which "invites participation from the viewer, who is able to walk along the tapestry in a physical sense but who is also drawn into it on an imaginative level" (67).

Chapter 3 shifts to a focus on altarpieces, exploring van Eycks' Ghent Altarpiece (1432) and Memling's St John Altarpiece (I 479). The Ghent Altarpiece, designed for a side chapel in St John's Cathedral, Ghent, brings together various parts of Revelation for didactic purposes, focusing on the Eucharist and resonances to this within the Apocalypse. O'Hear notes that, "Once freed from the constraints of a diachronic book-format, the artist can prioritize parts of a text, in this case the Eucharistic and celestial imagery, and leave others out completely" (87). Memling's piece, meanwhile, was situated at the St John's Hospital in Bruges. While Memling also brings several aspects of Revelation together, the focus here seems to be on offering reassurance to those who are coming to the end of their lives. These depictions of Revelation offer a chance to reflect on the hermeneutical interplay between an artistic piece and its function in a particular setting and context.

"The Mystic Nativity: Botticelli and the Book of Revelation" is the subject of the fourth chapter. O'Hear explores whether this painting, which at first appears to be a depiction of the Nativity, was influenced by the preaching of Girolamo Savonarola on Revelation, or if it is "the product of a more sustained interface with texts, ideas, and images relating to a broader late fifteenth-century cultural context" (I06). Because of this focus, this chapter 
has more historical reconstruction and presupposition than other parts of the study. Botticelli's work is again different from the other pieces explored in that it contains a Greek inscription that acts as an interpretative guide for a reader/viewer who is no doubt well learned. Key aspects of Revelation "are pictorialized, in non-mimetic fashion, as a Nativity scene” (I 33), and done so through the lens of Botticelli's Florentine.

Chapter 5 is a substantial portion of the book, looking at Late Medieval and Early Modern Germanic representations of Revelation. This chapter touches on the Koberger Bible of $\mathrm{I}_{4} 83$, but gives particular attention to the works of Albrecht Dürer and Lucas Cranach. Both artists produced woodcuts that accompanied the text of Revelation, an approach which presented the book in much more linear fashion than, for example, the representation of Botticelli, while simultaneously capitalising on developments in print media. Dürer's work is a standalone version of the Book of Revelation, where fifteen "large, full-page images jostle for precedence with the text and indeed, one could argue, ultimately overwhelm the text" (I37). Dürer's illustrations are primarily aesthetic, though there are critical theological themes embedded in the series. Cranach's twenty-one images, meanwhile, were commissioned by Luther to represent each chapter of Revelation. Luther wished the depictions to be "as true to the text and as visually simple as possible" (I 86), because of their illustrative and didactic purpose. O'Hear comments that "Where Dürer had allowed for synchronic, nuanced, and, at times ambiguous interpretations of the text, Cranach's illustrations generally admit only one interpretation, and one that is more or less imposed on the viewer" (I 38 ).

In chapter 6, O'Hear turns to "Hermeneutical Reflections and Visual Exegesis." Here the author moves beyond the work of laying out the visual reception history of the book of Revelation to discuss broader hermeneutical and exegetical questions related to these depictions. O'Hear explores the relationship of text and image, using Gadamer's concepts of Vorstellung and Darstellung as a template for the discussion, before moving on to explore the visionary character of Revelation and the implications of this for artistic depiction. This chapter uses the visual depictions examined throughout the book to explore the relationship between textual and visual exegesis, but also utilises more recent representations of Revelation, such as that of William Blake, that embody these various hermeneutical tensions.

The book draws to a close with a short conclusion which is more of a reflection on the final chapter than a conclusion to the study as a whole, followed by three appendices. 
This is a fine study, modelling research that is thorough and scholarship that is truly interdisciplinary. In spite of the increased interest in reception history within biblical studies, substantial contributions in this particular area have been slow to emerge, particular from the side of biblical scholarship. O'Hear's study is a welcomed addition, not least because it is a serious attempt to bring biblical, artistic, and hermeneutical reflections into conversation with one another. Further, the volume has forty-three high quality colour reproductions of the various visual depictions under discussion that enrich the reading/viewing/interpretative experience that lies at the heart of the study.

There are issues with which one might quibble. For instance, elements of the project's origins as a thesis remain evident. The first appendix on the visionary nature of Revelation bears little relation to the rest of the study, and adds minimally to the volume. Of more interest to readers of this journal may be O'Hear's methodological reflections on reception and the relation of her work to others in the field; here I was left, on the whole, unconvinced. O'Hear sees herself building on but eventually diverging from those who have worked in the area of visual exegesis, notably Berdini and O'Kane. The author is concerned that these scholars end up subordinating visual exegesis to textual exegesis. This notion, however, is underdeveloped in the study, and it is not entirely clear that this is a fair reading of either of these scholars. The fact that the book concludes on these issues detracts from the important and careful work done elsewhere in the body of the study.

It spite of these reservations, O'Hear is to be commended for this volume, both for the depth of its research, as well as the demonstration it provides of the promise of interdisciplinary research at the intersection of biblical studies and visual reception history. 